\title{
Klinikinis atvejis: Guillain-Barré sindromas ir galima asociacija su Laimo liga
}

\section{Muliuolis* \\ E. Tilindytė* \\ R. Samaitiené $\dot{e}^{* *}$ \\ *Vilniaus universiteto \\ Medicinos fakultetas}

**Pediatrijos centras, Vilniaus universiteto Medicinos fakultetas

\begin{abstract}
Santrauka. Guillain-Barré sindromas (GBS) yra ūminė uždegiminė demielinizuojanti ar aksonus pažeidžianti polineuropatija. Jai būdingi jutimo, motorikos ir refleksų sutrikimai, galvinių nervų pažeidimas, autonominiai sutrikimai, rečiau gali pasireikšti centrinės nervų sistemos pažeidimai. Tai - gyvybei pavojinga būklè, dèl kurios pacientai skubiai kreipiasi ị prièmimo-skubios pagalbos skyrių dèl progresuojančio skausmo, paralyžiaus ir (arba) kvėpavimo sutrikimų, kurie, laiku neskyrus gydymo, gali baigtis mirtimi. Ankstyvas šios būklès diagnozavimas ir gydymas yra labai svarbūs siekiant užkirsti kelią letaliai baigčiai. Nors su GBS etiologija siejama daugybė infekcijų, ryšys su Laimo liga nustatomas labai retai. Laimo liga - tai Ixodes genties erkiu platinamų Borrelia burgdorferi sukeliama infekcija, pasireiškianti odos, sąnarių, nervų sistemos ir širdies pažeidimais. Straipsnyje aprašomas klinikinis atvejis: 8 metų pacientas, kuriam buvo diagnozuotas GBS ir Laimo liga, esant atitinkamiems klinikiniams požymiams, įskaitant meninginius simptomus, progresuojantị tirpimą ir silpnumą rankose bei kojose abipus per ne visą savaitę, veidinio nervo abipusę parezę ir arefleksiją. Nors GBS diagnozė buvo neabejotina, Laimo ligos diagnostika buvo apsunkinta dèl ịvairiu aplinkybių, kurias nagrinėdami ieškojome kliniškai reikšmingo ryšio tarp abiejų minètų patologijų. Pradejjus gydymą intraveniniu imunoglobulinu ir ceftriaksonu, paciento simptomai palaipsniui išnyko.
\end{abstract}

Raktažodžiai: Guillain-Barré sindromas, Laimo liga, molekulinė mimikrija, diagnostiniai sunkumai.

\section{IVADAS}

Guillain-Barré sindromas (GBS) yra gyvybei pavojinga liga, kai organizmo imuninè sistema puola periferinę nervų sistemą. Jai būdingas staiga atsirandantis raumenų silpnumas, kuris gali sukelti kvėpavimo nepakankamumą ir mirtị. Pirmieji simptomai paprastai yra parestezijos ir apatinių galūnių silpnumas [1]. Tiksli GBS priežastis nežinoma, tačiau jam būdinga neseniai buvusi infekcinè liga, tokia kaip kvėpavimo takų infekcija ar virusinis gastroenteritas. GBS pasitaiko visame pasaulyje. Metinis sergamumas yra nuo 0,6 iki 2,4 atvejo 100000 asmenų, kuriems yra daugiau kaip 18 metų [2]. Vyrai paveikiami maždaug 1,5 karto daž-

\author{
Adresas: \\ Rūta Samaitienè \\ Vaiku ligoninè viešosios įstaigos Vilniaus universiteto \\ ligonines Santaros kliniku filialas, Pediatrijos centras \\ Santariškiu g. 4, LT-08661 Vilnius \\ El.paštas ruta.samaitiene@mf.vu.lt
}

niau nei moterys visose amžiaus grupėse. Vaikams ligos dažnis yra mažesnis nei suaugusiesiems [3].

Guillain-Barré sindromą dažniausiai sukelia Campylobacter jejuni, rečiau citomegalo virusas, Epšteino-Baro virusas ir žmogaus imunodeficito virusas (ŽIV) [4] (1 lentelè). Iš visų infekcinių ligų sukèlèjų, susijusių su GBS, Borrelia genties spirochetos yra vienos iš rečiausiai GBS asocijuotų patogenų. Remiantis Patelio ir kolegų atliktu tyrimu, iki 2017 m. literatūroje aprašyti tik keturi tokie atvejai [5].

Laimo liga (LL) yra multisisteminè zoonozè, kurią sukelia Borrelia genties spirochetos ir perneša Ixodes genties erkès, kurios užsikrečia borelijomis besimaitindamos natūralių gamtinių rezervuarų krauju [6]. Dažnos klinikinès apraiškos yra odos, sąnarių, nervų sistemos ir širdies pažeidimai. Nervų sistema ị patologinị procesą ịtraukiama tik esant išplitusiai infekcijai. Neuroboreliozė išsivysto iki $40 \%$ pacientų [7], nors kai kurie tyrimai rodo mažesnị paplitimą 10-15 \% [8]. Ūminès neuroboreliozès klasikinė klinikinè triada apima limfocitinị meningitą, kaukolès

(C) Neurologijos seminarai, 2019. Open Access. This article is distributed under the terms of the Creative Commons Attribution 4.0 International License CC-BY 4.0 (http://creativecommons.org/licenses/by/4.0/), which permits unrestricted use, distribution, and reproduction in any medium, provided you give appropriate credit to the original author(s) and the source, provide a link to the Creative Commons license, and indicate if changes were made. 
1 lentelè. GBS sukèlèjai ir jų paplitimas

\begin{tabular}{||l|c||}
\hline Guillain-Barré sindromo sukėlèjas & Paplitimas \\
\hline Campylobacter jejuni & $32 \%$ \\
\hline Citomegalo virusas & $13 \%$ \\
\hline Epstein-Barr virusas & $10 \%$ \\
\hline Mycoplasma pneumoniae & $5 \%$ \\
\hline Haemophilus influenzae & $1 \%$ \\
\hline Parainfluenzae 1 virusas & $1 \%$ \\
\hline Influenza A virusas & $1 \%$ \\
\hline Influenza B virusas & $1 \%$ \\
\hline Adenovirusas & $1 \%$ \\
\hline Herpes simplex virusas & $1 \%$ \\
\hline Varicella zoster virusas & $1 \%$ \\
\hline
\end{tabular}

neuropatiją ir skausmingą radikulopatiją. Periferinès nervų sistemos (PNS) apraiškos apima kaukolès neuropatijas, radikuloneuritą ir kitas periferinių nervų formas [9]. Neuroboreliozė retai gali pasireikšti kaip ị GBS panašus sindromas [10]. Neurologiniams pažeidimams būdingi: meningitas, veidinio nervo neuropatija (Bell'o paralyžius) ir periferinès radikulopatijos, šios būklès išnyksta po gydymo [11]. Dabartinėse rekomendacijose suaugusiems pacientams, esant neuroboreliozei, nurodomas gydymas intraveniniu ceftriaksonu 2-4 savaites [12]. Užkrečiamųju ligų ir AIDS centro duomenimis, $2018 \mathrm{~m}$. buvo stebimas kiek mažesnis sergamumas LL nei tuo pačiu metu $2017 \mathrm{~m}$. Lietuvoje $2018 \mathrm{~m}$. užregistruoti 2293 LL atvejai, o 2017 m. - 2826 atvejai. Manoma, kad sergamumo svyravimas stebimas dèl erkèms nepalankių klimatinių sąlygų itin sausos vasaros. Vis dèlto sergamumas išlieka didelis 13,7 atvejo 100000 gyventoju [13].

Laimo liga, kaip galimas etiologinis veiksnys, užvedantis GBS patogenezę, dar nèra išsamiai išnagrinètas medicinos mokslo bendruomeneje. Taip yra dèl galutinai neišaiškinto ryšio tarp organizmo infekavimo borelijomis ir GBS patogenezès. Šiuo metu ryšį mėginama aiškinti pagal imuninio atsako sąlygoto uždegimo ịtaką glijos ir neuronų pažeidimui bei molekulinès mimikrijos mechanizmą.

\section{ATVEJO APRAŠYMAS}

A.K., aštuonerių metu berniukas, buvo hospitalizuotas ị stacionarą dèl galvos ir raumenų skausmo, labiausiai žastu ir šlaunų srityse, bei sutrikusios eisenos ir bendro silpnumo. Prieš dvi dienas žaisdamas mokykloje nukrito, staiga atsiradus bendram silpnumui. Vèliau aktyvios fizinès veiklos metu pacientas pajuto raumenų silpnumą, ịprasta fizinė apkrova tapo per sunki. Naktį atsirado stiprus galvos skausmas, kurị pavyko numalšinti analgetikais. Kitą dieną paciento būklè pablogèjo, berniukui tapo sunku laikyti ịprastus, lengvus daiktus, skaudẻjo galūnių raumenis. Trečios dienos rytą berniukas nepajègè atsikelti ir stovèti. $\mathrm{Pa}$ cientas serga bronchine astma, dažnai kartojasi bronchitai.
Paskutinis pablogèjimas buvo prieš du mėnesius, gydėsi ventolinu ir amoksicilino tabletėmis. Buvo stebèta kūnu ropojanti erkè, tačiau bẻrimų po to nebuvo, todèl i gydytojus nesikreipè.

Atvykus ị ligoninę, apžiūros metu stebèti teigiami meninginiai simptomai, Rombergo pozoje buvo nestabilus, nustatytas padidejęs arterinis kraujo spaudimas (AKS). Atliktoje galvos kompiuterinejje tomografijoje rasta netiesioginių intrakranijinès hipertenzijos požymių, skirtas gydymas skysčių infuzija, manito $10 \% 150 \mathrm{ml}$ tirpalu, enalaprilio $10 \mathrm{mg}$ ir furozemido $10 \mathrm{mg}$ tabletėmis. Tačiau AKS išliko padidèjęs, meninginiai simptomai - silpnai teigiami. Atliktoje 12 derivacijų EKG - sinusinè tachikardija. Bendras šlapimo tyrimas, kreatininas, glomerulų filtracijos greitis patologijos nerodè.

Ketvirtą ligos dieną berniukas prilaikomas galëjo žengti tik kelis žingsnius, iš gulimosios padèties pats atsisèsti negalëjo, atsirado abipusis veido raumenų silpnumas. Raumenys buvo simetriškai hipotoniški, rasta dizestezija, sausgyslių refleksai rankose - silpnai teigiami, kojose arefleksija, patologinių refleksų nebuvo. Užkietėjo viduriai.

Nustatyta kvadriparezė su proksimaliniu galūnių silpnumu (raumenų jèga rankose - 3 balai, kojose - 2 balai), autonominè vegetacinė disfunkcija (galūnių hiperhidrozé, odos paraudimas, obstipacija, nestabili arterinè hipertenzija, tachikardija), kairiojo (vèliau ir dešiniojo) veidinio nervo neuropatija (3 balai pagal House-Brackmann skalę). İtarus Guillain-Barré polineuropatiją, pacientas perkeltas ị Vaikų intensyviosios terapijos skyriu (VITS).

Penktą hospitalizacijos dieną atliktas likvoro tyrimas: rasti padideję gliukozès ir baltymo kiekiai $(4,5 \mathrm{mmol} / \mathrm{l}$ ir $1,651 \mathrm{~g} / 1$ atitinkamai). Autoimuninio encefalito antikūnu mozaika iš likvoro ir serumo buvo neigiama. Neuroboreliozès imunoglobulinų $\mathrm{G}(\operatorname{IgG})$ serume rastas ribinis kiekis $(5,5 \mathrm{U} / \mathrm{ml}), \operatorname{IgM}$ serume rastas didelis padidejimas ( $>60 \mathrm{U} / \mathrm{ml}$ ), esant praskiedimui 1:400 bei 1:1000. Taip pat rasta $>60 \mathrm{U} / \mathrm{ml} \operatorname{IgM}$ likvore, esant praskiedimui $1: 2$ bei $1: 10$. Buvo atliktas IgG imunoblotas iš to paties serumo: rasti antikūnai prieš p41 ir OspC, bei IgM imunoblotas: antikūnai prieš p41 ir OspC-adv Bg, OspC-adv Bsp. Antikūnų indeksui arba albumino IgG/M likvore ir serume santykiui apskaičiuoti likvoro neužteko, todèl šis rodiklis liko nežinomas. Paciento elektroneuromiogramoje (ENMG) nustatyti pakitimai, būdingi mišriai motorinei ir sensorinei polineuropatijai: motorinių nervų tyrime buvo stebima pailgèjusi distalinè piko latencija, sumažèjusi amplitudè, sulètėjęs laidumo greitis; sensorinio $n$. ulnaris dex. pailgèjusi distalinè piko latencija, sumažejusi amplitudè, sulètèjęs laidumo greitis (2 lentelè).

Remiantis anamneze, klinikiniais ir laboratoriniais tyrimais, diagnozuotas galimai Laimo ligos sukeltas GBS. VITS pacientas skundėsi kojų skausmu ramybėje ir niežuliu, simptomai pradejjo mažèti palaipsniui nuo pirmos gydymo dienos: trečią ligos dieną skirta imunoglobulino $15 \mathrm{~g}$ infuzija $\mathrm{i} / \mathrm{v}(5 \mathrm{~d}$.) ir penktą ligos dieną pridètas ceftriaksonas $2 \mathrm{~g} \mathrm{i} / \mathrm{v}(21 \mathrm{~d}$.) Tuo pat metu buvo tęsiamas gydymas skysčių infuzija, manitoliu, taip pat skirti antihistamininiai 
2 lentelè. Motorinių (viršuje) ir sensorinių (apačioje) nervų elektrinio laidumo tyrimas

\begin{tabular}{|c|c|c|c|c|c|c|c|c|c|c|c|}
\hline Site & NR & $\begin{array}{c}\text { Onset } \\
(\mathrm{ms})\end{array}$ & $\begin{array}{l}\text { Norm } \\
\text { Onset } \\
\text { (ms) }\end{array}$ & $\begin{array}{c}\text { O-P } \\
\text { Amp } \\
(\mathrm{mV})\end{array}$ & $\begin{array}{l}\text { Norm } \\
\text { O-P } \\
\text { Amp }\end{array}$ & Site1 & Site2 & $\begin{array}{c}\text { Delta-0 } \\
\text { (ms) }\end{array}$ & $\begin{array}{l}\text { Dist } \\
\text { (cm) }\end{array}$ & $\begin{array}{c}\mathrm{Vel} \\
(\mathrm{m} / \mathrm{s})\end{array}$ & $\begin{array}{c}\text { Norm } \\
\text { Vel } \\
(\mathrm{m} / \mathrm{s})\end{array}$ \\
\hline \multicolumn{12}{|c|}{ Right Median Motor (Abd Poll Brev) } \\
\hline Wrist & & 16.4 & $<4.2$ & 0.9 & $>5$ & Elbow & Wrist & 6.9 & 14.5 & 21 & \multirow[t]{3}{*}{$>50$} \\
\hline Elbow & & 23.3 & & 0.8 & & Axilla & Elbow & 5.3 & 7.0 & 13 & \\
\hline Axilla & & 28.6 & & 0.5 & & & & & & & \\
\hline \multicolumn{5}{|c|}{ Right Peroneal Motor (Ext Dig Brev) } & \multirow{3}{*}{$>2.5$} & \multirow{3}{*}{ B Fib } & \multirow{3}{*}{ Ankle } & \multirow{3}{*}{11.0} & \multirow{3}{*}{32.0} & & \multirow{3}{*}{$>38$} \\
\hline Ankle & & 8.7 & $<6.1$ & 0.7 & & & & & & 29 & \\
\hline B Fib & & 19.7 & & 0.3 & & & & & & & \\
\hline \multicolumn{5}{|c|}{ Right Tibial Motor (Abd Hall Brev) } & \multirow{3}{*}{$>3.0$} & \multirow{3}{*}{ Knee } & \multirow{3}{*}{ Ankle } & \multirow{3}{*}{11.1} & \multirow{3}{*}{29.0} & & \multirow{3}{*}{$>35$} \\
\hline Ankle & & 6.3 & $<6.1$ & 0.9 & & & & & & 26 & \\
\hline Knee & & 17.4 & & 0.2 & & & & & & & \\
\hline \multicolumn{5}{|c|}{ Right Ulnar Motor (Abd Dig Minimi) } & \multirow{4}{*}{$>3$} & \multirow{4}{*}{$\begin{array}{l}\text { B Elbow } \\
\text { A Elbow }\end{array}$} & \multirow{4}{*}{$\begin{array}{l}\text { Wrist } \\
\text { B Elbow }\end{array}$} & \multirow{4}{*}{$\begin{array}{l}6.9 \\
3.8\end{array}$} & \multirow{4}{*}{$\begin{array}{l}15.0 \\
8.5\end{array}$} & & \multirow{4}{*}{$\begin{array}{l}>52 \\
>53\end{array}$} \\
\hline Wrist & & 5.5 & $<4.2$ & 1.0 & & & & & & 22 & \\
\hline B Elbow & & 12.4 & & 0.5 & & & & & & 22 & \\
\hline A Elbow & & 16.2 & & 0.3 & & & & & & & \\
\hline Site & NR & $\begin{array}{c}\text { Peak } \\
\text { (ms) }\end{array}$ & $\begin{array}{l}\text { Norm } \\
\text { Peak } \\
(\mathrm{ms})\end{array}$ & $\begin{array}{c}\text { P-T } \\
\text { Amp } \\
(\mu \mathrm{V})\end{array}$ & $\begin{array}{c}\text { Norm P- } \\
\text { T Amp }\end{array}$ & Site1 & Site2 & $\begin{array}{c}\text { Delta-P } \\
\text { (ms) }\end{array}$ & $\begin{array}{l}\text { Dist } \\
\text { (cm) }\end{array}$ & $\begin{array}{c}\text { Vel } \\
(\mathrm{m} / \mathrm{s})\end{array}$ & $\begin{array}{c}\text { Norm } \\
\text { Vel } \\
(\mathrm{m} / \mathrm{s})\end{array}$ \\
\hline \multicolumn{11}{|c|}{ Right Median Anti Sensory (2nd Digit) } & \multirow[b]{2}{*}{$>39$} \\
\hline Wrist & & 13.8 & $<3.6$ & 11.0 & $>10$ & Wrist & 2nd Digit & 13.8 & 13.0 & 9 & \\
\hline \multicolumn{5}{|c|}{ Right Sural Anti Sensory (Lat Mall) } & \multirow{3}{*}{$>5.0$} & \multirow{3}{*}{ Calf } & \multirow{3}{*}{ Lat Mall } & \multirow{3}{*}{26.3} & \multirow{3}{*}{14.0} & & \\
\hline Calf & & 26.3 & $<4.0$ & 23.8 & & & & & & 5 & $>35$ \\
\hline Site 2 & & 23.9 & & 11.0 & & & & & & & \\
\hline Right Ul & ar An & Sensory & (5th Digit) & & & & & & & & \\
\hline Wrist & & 8.3 & $<3.7$ & 8.2 & $>15.0$ & Wrist & 5th Digit & 8.3 & 11.0 & 13 & $>38$ \\
\hline B Elbow & & 1.5 & & 3.1 & & B Elbow & Wrist & 6.8 & 0.0 & & $>47$ \\
\hline
\end{tabular}

bei hormoniniai preparatai alerginių reakcijų gydymui ir simptominis skausmo gydymas finlepsinu.

Tolesnè ligos eiga buvo su teigiama dinamika: palaipsniui pagerėjo bendra būklè ir galūnių raumenų jèga, nors išliko autonominè disfunkcija. Širdies ritmo sutrikimų nenustatyta, paros AKS tyrimo metu nustatyta arterinė hipertenzija, kuriai gydyti skirtos padidintos enalaprilio dozès. Po 4 savaičiu raumenų jèga galūnèse buvo 3-4 balai (gravitaciją įveikia), silpna rankų gniaužimo jèga dešiniaja ranka $-5 \mathrm{~kg}$, kairiaja ranka $-4 \mathrm{~kg}$, eisena netvirta ir nestabili, sutrikusi pusiausvyra ir koordinacija (pagal Tinetti skalę 19 balų), kartais jaute parestezijas, skausmus blauzdų nugariniame paviršiuje, VAS (vizualinė analoginė skalè) - iki 5 balų, Barthel indeksas - 65 balai.

\section{APTARIMAS}

GBS išsivystymas siejamas su bakterinėmis ir virusinèmis infekcijomis, jų metu išprovokuojamas imuninis atsakas prieš periferinių nervų komponentus dèl vykstančios kryžminès reakcijos (molekulinès mimikrijos mechanizmas) [14]. Imuninès reakcijos su Švano dangalo ląstelių paviršiaus membrana ar mielinu sukelia ūminę uždegiminę demielinizuojančią neuropatiją (85\%), o reakcija su aksono membrana - ūminę aksoninę neuropatiją (15\%) [15].

Gangliozidai yra svarbi plazminės membranos dalis, ypač jų gausu nervų sistemoje. Bakterijų paviršiuje randa- mų lipopolisacharidų (LPS) molekulinė sudètis yra identiška gangliozidams, todèl susidaręs imuninis atsakas prieš bakterijos antigenus veikia ir šeimininko organizmo ląsteles. Dažniausiai su GBS siejama Campylobacter jejuni, įvairių mokslinių straipsnių duomenimis, šios infekcijos metu randami antigangliozidiniai $\operatorname{IgA}, \operatorname{IgG}, \operatorname{IgM}$ antikūnai prieš: GM1, GM1b, GQ1b, GD1a, GalNac-GD1a, GD1b [16-17]. Tuo tarpu Cytomegalo ir Epstein-Barr virusų sukeltas GBS siejamas su antigangliozidiniais antikūnais prieš GM2, nors jų svarba nėra patvirtinta.

Tyrimai su triušiais parodė, kad, sensibilizavus gyvūnèlius su GM1, susidarè anti-GM1 IgG antikūnai, pasireiškẻ galūnių silpnumas ir buvo stebimi identiški patologiniai pažeidimai periferiniuose nervuose [18]. Tolesni tyrimai parodè, kad patologinio proceso metu yra sukeliama natrio kanalų blokada ir tai lemia grịžtamus nervo laidumo sutrikimus [19].

Imuninès reakcijos, nukreiptos prieš Švano ląstelių paviršiaus epitopus membranoje ar mieline, gali sukelti ūmią uždegiminę demielinizuojančią neuropatiją [20]. Patologinis mechanizmas yra daugiažidininė uždegiminė demielinizacija, prasidedanti nuo nervinių šaknelių lygio. Ankstyviausi pokyčiai dažnai pastebimi Ranvier mazguose. Aktyvuotų T-ląstelių reakciją seka makrofagų sukelta demielinizacija, stebima komplemento ir imunoglobulinụ depozicija mielino ir Švano ląstelèse [21]. Turime pastebėti, kad GBS retais atvejais gali sukelti ir kitos priežastys: imunizacija, operacija, trauma ar kaulų čiulpų transplanta- 
cija [22-23]. Visgi, mūsų aprašomu atveju šios priežastys nebuvo nustatytos.

Šeimininko imuninis atsakas yra pagrindinis veiksnys Laimo ligos patogenezèje. B. burgdorferi negamina toksinų ar proteazių, tiesiogiai žeidžiančių audinius, o ekspresuoja išorinius membranos baltymus, selektyviai sąveikaujančius su endotelio ląstelėmis, trombocitais, chondrocitais ir tarpląsteline matrica per integrinus, glikozaminoglikanus, fibronektiną ir kolageną [24]. Borelijos yra atsparios fagocitozei ir bakteriocidiniams veiksniams kraujyje, todèl greitai išplinta po audinius ir patenka ị centrinę nervų sistemą (CNS), kur intensyviai dauginasi [25]. Šiuo metu nèra žinoma, kaip borelijos įveikia hematoencefalinị barjerą. Literatūroje aprašomi 2 galimi būdai: skverbimasis endotelio ląstelių tarpais [26] arba transceliulinis transportas [27]. Borelijų sąveika su šeimininko audiniais sąlygoja imuninį atsaką: be B limfocitų ir plazminių ląstelių CNS kaupiasi ir aktyvuotos CD8+ T ląstelès, pritrauktos vietinių chemokinų (CCL4, CCL5, CXCL10 ar CXCL11) [28]. Patologiniais Laimo neuroborelioze (LNB) sirgusių pacientų tyrimais patvirtinta limfocitų ir plazminių ląsteliụ infiltracija voratinkliniame ir minkštajame dangaluose bei perivaskuliniai imuninių ląstelių infiltratai šalia baltosios medžiagos pažeidimų smegenyse, ir skersinio mielito pažeistų plotų nugaros smegenyse [29]. Sirgusiems PNS borelioze nustatyti uždegiminiai pakitimai nervų šaknelèse ir užpakalinių šaknelių ganglijuose bei pavieniai daugiažidininiai aksonų praradimo plotai, lydimi epineuralinių perivaskulinių uždegiminių infiltratų ar perineurito [30]. Atliekant tyrimus su makakomis, inokuliuotomis B. burgdorferi i cisterna magna, buvo stebima demielinizacija visų užkrèstų makakų nugarinių nervų šaknelèse. Šio tyrimo autoriai tvirtina, kad glijos ir neuronų apoptoze skatina B. burgdorferi indukuota uždegiminè aplinka [31]. Greta uždegimo mediatoriu turi būti svarstomas ir autoimuninių reakcijų mechanizmas Laimo ligos neurologinių pažeidimų patogenezejje. Borelijų sukeltos autoimuninès reakcijos arba molekulinè mimikrija taip pat galètų būti svarbus aspektas stebimoje nervų disfunkcijoje. Kryžminiai antikūnai gali atsirasti sergančiųjų Laimo borelioze serume [32], nes jame esantys antikūnai prieš $B$. burgdorferi flageliną kryžmiškai reaguoja su nervinių ląstelių antigenais [33]. Mokslinèje literatūroje aprašomi ịvairūs atvejai, kai Laimo liga inicijavo molekulinès mimikrijos mechanizmus. Mechanizmas siejamas su lètiniu artritu, kurio simptomai išlieka ir sunaikinus bakterinę infekciją [34]. Rasti antigeniniai panašumai tarp $41 \mathrm{kDa}$ žiuželinio baltymo ir ịvairių žmogaus audinių: ypač išreikšta sąsaja tarp mielino skaidulų periferiniuose nervuose ir centrinès nervų sistemos neuronų aksonuose [35-36].

Tikrasis GBS ir Laimo ligos sąsajos mechanizmas išlieka neaiškus, tačiau yra duomenų apie imuninę reakciją, susijusią su borelijų patogenais. Manoma, kad, susidarant imuniniams kompleksams, susidaro ir antigangliozidiniai antikūnai, lemiantys GBS [37].

Mūsų nagrinėjamu atveju Guillian-Barré sindromo diagnozė yra neabejotina. Ši liga diagnozuojama kliniškai, mūsų pateiktame atvejyje simptomai atitiko GBS. Iš klini- kinių požymių ir tyrimų duomenų nustatėme ir ligos formą - mūsų pacientui stebėta ūminė uždegiminè demielinizuojanti polineuropatija (acute inflammatory demyelinating polyneuropathy, ADIP). Tyrimai, patvirtinantys diagnozę: padidejusi baltymo koncentracija cerebrospinaliniame skystyje $>45 \mathrm{mg} / \mathrm{dL}$ su nepakitusiu leukocitų skaičiumi (albumino citologinė disociacija) [38]. Taip pat būdingi ENMG tyrimo pakitimai: laidumo blokas, sumažejęs motorinio ir jutiminio nervo laidumas, ilga distalinė latencija [39]. Paciento tyrimuose buvo stebimi analogiški pakitimai.

Siekiant susieti GBS su LNB, reikia patikimais diagnostiniais metodais patvirtinti borelijų infekciją. Laimo ligos diagnostika priklauso nuo ligos stadijos. Esant ankstyvai lokalizuotai infekcijai, diagnostika remiasi klinikiniais požymiais, iš kurių dažniausias ir specifiškiausias yra migruojanti eritema (ME) [40]. Pastebejjus šị bėrimą, papildomi tyrimai etiologijai patvirtinti neatliekami dèl stadijai būdingo seronegatyvumo [41]. Tačiau ME nebuvimas ar nepastebejjimas nepaneigia ligos diagnozès. Šiuo metu priimta atlikti serologinius tyrimus, kai stebimi ankstyvos diseminuotos ar vėlyvos diseminuotos ligos požymiai (meningitas, radikulopatija, mononeuritas, veidinio nervo paralyžius, artritas, karditas), nes, ligai progresavus, yra būdingi padidèję specifinių antikūnų titrai [42-43]. Geriausia naudoti jautrius imunologinius tyrimus: ELISA (gali būti pakeistas imunofluorescenciniu tyrimu (IFA immunofluorescent assay)) bei Western blot. Teigiamas Western blot tyrimas patvirtina kontaktą su B. burgdorferi ir nusveria rezultatus, gautus ELISA ar IFA tyrimais. IgM ir IgG antikūnai tiriami atskirai [44]. Literatūroje teigiama, kad vien teigiamas IgM rezultatas neturètų būti naudojamas Laimo ligos diagnozei patvirtinti pacientams, kuriems ankstyvos infekcijos simptomai nepasireiškè per 6-8 savaites be gydymo [45]. Jei po to pacientui IgM ELISA ir IgM Western blot rezultatai yra teigiami, tačiau neigiami IgG, IgM testas greičiausiai rodo klaidingai teigiamą rezultatą arba anksčiau gydytą infekciją [46].

Mūsų aprašomo paciento klinikiniai požymiai atitiko būdingus ankstyvajai diseminuotai fazei: stebèti meninginiai simptomai, radikulitas (Garin-Bujadoux-Bannwarth sindromas), abipusè veidinio nervo parezė. Epidemiologinẻ anamnezè - teigiama (gyvena arti miško, stebejjo kūnu ropojančią erkę). Tačiau įsisegusios erkès ir ankstyvos lokalizuotos fazès požymių nestebèta, todèl tai apsunkino ligos diagnozę. Ankstyva diseminuota fazè, esant galvinių nervų parezei, turi būti patvirtinta serologiniais tyrimais, $\mathrm{o}$ esant ribiniam ar teigiamam IgM Ak atsakymui, rekomenduojama atlikti imunoblotą iš to paties serumo. Mūsų paciento imunobloto IgM rezultatai buvo teigiami prieš borelijų antigenus, IgG - nepakankami. Ankstyvoje ligos stadijoje reikalingos dvi IgM grandinės iš dažniausių 8 [47]. Pacientui rasti teigiami IgM antikūnai prieš p41, OspC-adv $\mathrm{Bg}$, OspC-adv Bsp. Tiriant IgG, pacientui rasti teigiami p41 ir OspC, tačiau vėlyvai infekcijai patvirtinti reikalingos 5 iš 10 dažniausių IgG grandinių [47]. Ivvertinus visus duomenis, galima galvoti apie ankstyvą, keletą savaičių trunkančią diseminuotą Laimo ligos fazę. 
Tokiu atveju rekomenduojama kartoti tyrimą po 4-6 savaičių, tačiau mūsų pacientui tyrimas nekartotas dèl pagerèjusios būklès. Likvoro tyrimo rezultatų interpretaciją, diagnozuojant neuroboreliozę, apsunkino nepakankamas likvoro eminio kiekis ir tai, kad, nors nustatytas padidẻjęs baltymo kiekis, nežymiai padidèjęs laktatas ir nežymiai sumažèję chloridų, buvo nepakankama citozè. Taip pat antikūnų indeksui arba albumino IgG/M likvore ir serume santykiui apskaičiuoti likvoro neužteko, todèl šis rodiklis lieka nežinomas. Šiuo metu priimta Laimo ligos gydymą pradèti nesulaukus tyrimų rezultatų, jeigu pakanka epidemiologinių ir klinikinių duomenų. Dèl šios priežasties paciento gydymas buvo pradètas ceftriaksonu. Šiuo atveju pakankami IgG titrai galëjo nesusidaryti dèl anksti pradèto gydymo ir ankstyvos Laimo ligos fazès. Statistiniais duomenimis, GBS dažniausiai prasideda nuo $2 \mathrm{iki}$ 4 sav. po infekcijos [48], o Laimo ligos IgG susidarymui reikalingos 4 sav. [49], galimai dèl to mūsų pacientui serologinio tyrimo èminio metu nesusidare pakankami IgG titrai.

Apibendrindami galime teigti, kad mūsų aprašomu atveju nenustatyta visiškai aiški sąsaja tarp Laimo ligos ir GBS. Tam tikri paciento laboratoriniai duomenys, liudijantys apie Laimo ligą, yra nepakankami, tačiau, remdamiesi literatūros apžvalga, esame linkę manyti, kad mūsų pacientas sirgo ankstyvosios diseminuotos fazès Laimo liga. GBS diagnozė yra visiškai pagrịsta. Pažymètina tai, kad, be Laimo ligos, neturime įrodymų apie kitą galimą etiologinị veiksnį, galëjusị išprovokuoti ši sindromą. Siekiant diagnozès pagrindimo tikslumo, svarbu atsižvelgti į laboratoriniams tyrimams naudojamų ėminių surinkimo techniką, laiku pakartoti imunologinius tyrimus ir kruopščiai ịvertinti paciento klinikinius simptomus, kurie, nesant vienareikšmių tyrimų rezultatų, padeda geriau atlikti diferencinę diagnostiką ir skirti adekvatų gydymą.

\section{PADE்KA}

Dékojame Pediatrijos centro gydytojoms, gydžiusioms šị pacientą ir padejjusioms surinkti duomenis - Rūtai Praninskienei, Astai Judickienei ir visam personalui, padejusiam pacientui pasveikti.

\section{Literatūra}

1. Donofrio PD. Guillain-Barré syndrome. Continuum (Minneap Minn) 2017; 23(5, Peripheral Nerve and Motor Neuron Disorders): 1295-309. https://doi.org/10.1212/ CON.0000000000000513

2. Sudulagunta SR, Sodalagunta MB, Sepehrar M, et al. Guillain-Barré syndrome: clinical profile and management. Ger Med Sci 2015; 13: Doc16. https://doi.org/10.1093/omcr/ omv054

3. Sejvar JJ, Baughman AL, Wise M, Morgan OW. Population incidence of Guillain-Barré syndrome: a systematic review and meta-analysis. Neuroepidemiology 2011; 36: 123-33. https://doi.org/10.1159/000324710
4. Samaan M, Venrooy A, Botros C, Puttagunta R. A new tick palsy: case of Guillian-Barre syndrome associated with Lyme disease. Neurology 2018; 90(15 supplement): P5.136.

5. Patel K, Shah S, Subedi D. Clinical association: Lyme disease and Guillain-Barre syndrome. Am J Emerg Med 2017; 35(10): 1583.e1-2. https://doi.org/10.1016/j.ajem. 2017.07.030

6. Koedel U, Fingerle V, Pfister H-W. Lyme neuroberreliosisepidemiology, diagnosis and management. Nat Rev Neurol 2015; 11(8): 446-56. https://doi.org/10.1038/nrneurol. 2015.121

7. Prasad A, Sankar D. Overdiagnosis and overtreatment of Lyme neuroborreliosis are preventable. Postgrad Med J 1999; 75(889): 650-6. https://doi.org/10.1136/pgmj. 75.889 .650

8. Halperin JJ. Diagnosis and management of Lyme neuroborreliosis. Expert Rev Anti Infect Ther 2018; 16(1): 5-11. https://doi.org/10.1080/14787210.2018.1417836

9. Thaisetthawatkul P, Logigian EL. Peripheral nervous system manifestations of lyme borreliosis. J Clin Neuromuscul Dis 2002; 3(4): 165-71. https://doi.org/10.1097/00131402200206000-00006

10. Kumar M, Singh R, Rashid M. Lyme polyradiculitis masquerading Guillain-Barre syndrome. J Pediatr Neurosci 2016; 11(4): 384-385. https://doi.org/10.4103/18171745.199483

11. Halperin JJ. Neurologic manifestations of lyme disease. Curr Infect Dis Rep 2011; 13(4): 360-6. https://doi.org/10.1007/ s11908-011-0184-x

12. Bratton RL, Whiteside JW, Hovan MJ, Engle RL, Edwards FD. Diagnosis and treatment of Lyme disease. Mayo Clin Proc 2008; 83(5): 566-71. https://doi.org/ 10.1016/S0025-6196(11)60731-3

13. Žiema - tinkamiausias metas skiepytis nuo erkinio encefalito. [Internetinis puslapis]. Užkrečiamų ligų ir AIDS centras. [Publikuota 2019-01-31, žiūrèta 2019-08-30]. Prieiga per internetą: http://www.ulac.lt/naujienos/pranesimai-spaudai/ ziema-tinkamiausias-metas-skiepytis-nuo-erkinio-encefalito

14. Yuki N, Hartung HP. Guillain-Barré syndrome. N Engl J Med 2012; 366: 2294-304. https://doi.org/10.1056/ NEJMra1114525

15. Parnarauskienė R. Guillain-Barre sindromas. Anatomija, etiopatogenezé, klinika, gydymas. Vilnius: Petro ofsetas, 2012.

16. Ogawara K, Kuwabara S, Mori M, Hatori T, Koga M, Yuki N. Axonal Guillain-Barré syndrome: relation to anti-ganglioside antibodies and Campylobacter jejuni infection in Japan. Ann Neurol 2000; 48(4): 624-31. https://doi.org/10.1002/1531-8249(200010)48:4<624::AID -ANA9 > 3.0.CO;2-O

17. Jacobs BC, Hazenberg MP, van Doorn PA, et al. Cross-reactive antibodies against gangliosides and Campylobacter jejuni lipopolysaccharides in patients with Guillain-Barré or Miller Fisher syndrome. J Infect Dis 1997; 175: 729-33. https://doi.org/10.1093/infdis/175.3.729

18. Yuki N, Susuki K, Koga M, et al. Carbohydrate mimicry between human ganglioside GM1 and Campylobacter jejuni lipooligosaccharide causes Guillain-Barre syndrome. Proc Natl Acad Sci U S A 2004; 101: 11404-9. https://doi.org/ 10.1073/pnas.0402391101

19. Yuki N, Kuwabara S. Axonal Guillain-Barré syndrome: carbohydrate mimicry and pathophysiology. J Peripher Nerv Syst 2007; 12: 238-49. https://doi.org/10.1111/j.1529-8027. 2007.00153.x 
20. Hahn AF. Guillain-Barré syndrome. Lancet 1998; 352: 635-41. https://doi.org/10.1016/S0140-6736(97) 12308-X

21. Asbury AK, Arnason BG, Adams RD. The inflammatory lesion in idiopathic polyneuritis. Its role in pathogenesis. Medicine (Baltimore) 1969; 48(3): 173-215. https://doi.org/ 10.1097/00005792-196905000-00001

22. Ropper AH, Wijdicks EFM, Truax BT. Guillain-Barré syndrome. Philadelphia: FA Davis, 1991; 57.

23. Rudant J, Dupont A, Mikaeloff Y, et al. Surgery and risk of Guillain-Barré syndrome: A French nationwide epidemiologic study. Neurology 2018; 91: e1220. https://doi.org/10.1212/WNL.0000000000006246

24. Institute of Medicine (US) Committee on Lyme Disease and Other Tick-Borne Diseases: The State of the Science. Critical needs and gaps in understanding prevention, amelioration, and resolution of Lyme and other tick-borne diseases: the short-term and long-term outcomes: workshop report. Washington (DC): National Academies Press (US), 2011.

25. Pritt BS, Mead PS, Johnson DKH, Neitzel DF, RespicioKingry LB, Davis JP, et al. Identification of a novel pathogenic Borrelia species causing Lyme borreliosis with unusually high spirochaetaemia: a descriptive study. Lancet Infect Dis 2016; 16(5): 556-64. https://doi.org/10.1016/S14733099(15)00464-8

26. Grab DJ, Perides G, Dumler JS, Kim KJ, Park J, Kim YV, et al. Borrelia burgdorferi, host-derived proteases, and the blood-brain barrier. Infect Immun 2005; 73: 1014-22. https://doi.org/10.1128/IAI.73.2.1014-1022.2005

27. Comstock LE, Thomas DD. Penetration of endothelial cell monolayers by Borrelia burgdorferi. Infect Immun 1989; 57: 1626-8. https://doi.org/10.1128/IAI.57.5.1626-1628. 1989

28. Baggiolini M. Chemokines and leukocyte traffic. Nature 1998; 392: 565-8. https://doi.org/10.1038/33340

29. Koc F, Bozdemir H, Pekoz T, Aksu HS, Ozcan S, Kurdak H. Lyme disease presenting as subacute transverse myelitis. Acta Neurol Belg 2009; 109: 326-9.

30. Vallat JM, Hugon J, Lubeau M, Leboutet MJ, Dumas M, Desproges-Gotteron R. Tick-bite meningoradiculoneuritis: clinical, electrophysiologic, and histologic findings in 10 cases. Neurology 1987; 37(5): 749-53. https://doi.org/ 10.1212/WNL.37.5.749

31. Ramesh G, Didier PJ, England JD, et al. Inflammation in the pathogenesis of lyme neuroborreliosis. Am J Pathol 2015, 185(5): 1344-60. https://doi.org/10.1016/j.ajpath. 2015.01.024

32. Alaedini A, Latov N. Antibodies against OspA epitopes of Borrelia burgdorferi cross-react with neural tissue. J Neuroimmunol 2005; 159: 192-5. https://doi.org/10.1016/ j.jneuroim.2004.10.014

33. Steere AC, Glickstein L. Elucidation of Lyme arthritis. Nat Rev Immunol 2004; 4(2): 143-52. https://doi.org/10.1038/ nri1267

34. Bolz DD, Weis JJ. Molecular mimicry to Borrelia burgdorferi: pathway to autoimmunity? Autoimmunity 2004; 37(5): 387-92. https://doi.org/10.1080/ 08916930410001713098

35. Aberer E, Brunner C, Suchanek G, Klade H, Barbour A, Stanek G, et al. Molecular mimicry and Lyme borreliosis: a shared antigenic determinant between Borrelia burgdorferi and human tissue. Ann Neurol 1989; 26(6): 732-7. https://doi.org/10.1002/ana.410260608
36. Dai Z, Lackland H, Stein S, Li Q, Radziewicz R, Williams S, et al. Molecular mimicry in Lyme disease: monoclonal antibody H9724 to B. burgdorferi flagellin specifically detects chaperonin-HSP60. Biochim Biophys Acta 1993; 1181(1): 97-100. https://doi.org/10.1016/09254439(93)90096-J

37. Cusick MF, Libbey JE, Fujinami RS. Molecular mimicry as a mechanism of autoimmune disease. Clin Rev Allergy Immunol 2012; 42(1): 102-11. https://doi.org/10.1007/ s12016-011-8294-7

38. DiCapua DB, Lakraj AA, Nowak RJ, Robeson K, Goldstein J, Patwa H. Relationship between cerebrospinal fluid protein levels and electrophysiologic abnormalities in Guillain-Barré syndrome. J Clin Neuromuscul Dis 2015; 17(2): 47-51. https://doi.org/10.1097/CND.0000000000000091

39. Dimachkie MM, Barohn RJ. Guillain-Barré syndrome and variants. Neurol Clin 2013; 31(2): 491-510. https://doi.org/ 10.1016/ j.ncl.2013.01.005

40. Hu LT. In the clinic. Lyme disease. Ann Intern Med 2012; 157(3): ITC2-2-ITC2-16. https://doi.org/10.7326/00034819-157-3-201208070-01002

41. Aguero-Rosenfeld ME, Wang G, Schwartz I, Wormser GP. Diagnosis of lyme borreliosis. Clin Microbiol Rev 2005; 18(3): 484-509. https://doi.org/10.1128/CMR.18.3. 484-509.2005

42. Hatchette TF, Davis I, Johnston BL. Lyme disease: clinical diagnosis and treatment. Can Commun Dis Rep 2014; 40(11): 194-208. https://doi.org/10.14745/ccdr.v40i11a01

43. Lantos PM, Auwaerter PG, Nelson CA. Lyme disease serology. JAMA 2016; 315(16): 1780-1. https://doi.org/10.1001/ jama.2016.4882

44. Centers for Disease Control and Prevention (CDC). Recommendations for test performance and interpretation from the Second National Conference on Serologic Diagnosis of Lyme Disease. MMWR Morb Mortal Wkly Rep 1995; 44: 590.

45. Branda JA, Aguero-Rosenfeld ME, Ferraro MJ, et al. 2-tiered antibody testing for early and late Lyme disease using only an immunoglobulin $\mathrm{G}$ blot with the addition of a VlsE band as the second-tier test. Clin Infect Dis 2010; 50(1): 20-6. https://doi.org/10.1086/648674

46. Marques AR. Laboratory diagnosis of Lyme disease: advances and challenges. Infect Dis Clin North Am 2015; 29(2): 295-307. https://doi.org/10.1016/j.idc.2015.02.005

47. Dressler F, Whalen JA, Reinhardt BN, Steere AC. Western blotting in the serodiagnosis of Lyme disease. J Infect Dis 1993; 167(2): 392-400. https://doi.org/10.1093/infdis/ 167.2.392

48. Tam CC, O'Brien SJ, Petersen I, Islam A, Hayward A, Rodrigues LC. Guillain-Barré syndrome and preceding infection with campylobacter, influenza and Epstein-Barr virus in the general practice research database. PLoS One 2007; 2(4): e344. https://doi.org/10.1371/journal.pone.0000344

\section{Muliuolis, E. Tilindytė, R. Samaitienè}

\section{CASE REPORT: GUILLAIN-BARRÉ SYNDROME AND POSSIBLE ASSOCIATION WITH LYME DISEASE}

\section{Summary}

Guillain-Barré syndrome (GBS) is an acute inflammatory demyelinating or axon-damaging polyneuropathy. It is characterized by sensory, motor and reflex disorder, damaged cranial 
nerves, autonomic disorders, and, less frequently, damage to the central nervous system. This is a life-threatening condition that urges patients to seek emergency treatment for progressive pain, paralysis and/or respiratory distress that can cause death in the absence of timely treatment. Early diagnosis and treatment of this condition are very important in preventing fatal outcome. Although many infections are associated with the etiology of GBS, correlation with Lyme disease is determined very rarely. Lyme disease is a tick-borne Borrelia burgdorferi infection that can cause lesions of multiple organ systems: usually the skin, joints, nervous system, and the heart. This case report presents an 8 -year-old boy who was admitted to the hospital because of progressive weakness in the extremities, meningeal signs, bilateral facial nerve paresis, and areflexia. The patient was diagnosed with GBS and Lyme disease; and symptoms of the patient gradually disappeared following the treatment with intravenous immunoglobulin and ceftriaxone. Although the diagnosis of GBS was definite, the diagnosis of Lyme disease was complicated by a variety of circumstances which we analyse in this article. We also discuss a possible connection between the two pathologies.

Keywords: Guillain-Barré syndrome, Lyme disease, molecular mimicry, diagnostic difficulties.

Gauta:

Priimta spaudai:

20191217
20191230 